\title{
Variations in otological presentation of lightning strike victims: Clinical report of 3 patients
}

\author{
Erbil Kılıç, M.D., ${ }^{1}$ Hakan Genç, M.D., ${ }^{2}$ Ümit Aydın, M.D., ${ }^{3}$ Burak Aşık, M.D., ${ }^{4}$ Bülent Satar, M.D. ${ }^{3}$
}

${ }^{1}$ Department of Otolaryngology, Head and Neck Surgery, Gülhane Military Medicine Academy, Haydarpaşa Training Hospital, İstanbul-Turkey

${ }^{2}$ Department of Otolaryngology, Head and Neck Surgery Department, Isparta Military Hospital, Isparta-Turkey

${ }^{3}$ Department of Otolaryngology, Head and Neck Surgery Gülhane Military Medicine Academy, Ankara-Turkey

${ }^{4}$ Department of Otolaryngology, Head and Neck Surgery, Şırnak Military Hospital, Şırnak-Turkey

\begin{abstract}
Lightning strike can cause fatal or nonfatal injuries. Some nonfatal injuries are associated with otological symptoms and findings. Conductive hearing loss due to rupture of the tympanic membrane is the most common audiovestibular lesion of lightning strike.Various forms of sensorineural hearing loss and dizziness have also been reported. Presently described are 3 cases of lightning strike injury. First patient had mid-frequency hearing loss in right ear and high frequency sensorineural hearing loss in left ear. Second patient had high frequency sensorineural hearing loss in left ear, and the third had peripheral facial palsy with perilymphatic fistula on same side. This is the first documented case of mid-frequency hearing loss occurring after lightning strike.
\end{abstract}

Keywords: High frequency hearing loss; lightning strike; mid-frequency hearing loss; perilymphatic fistula; peripheral facial nerve palsy.

\section{INTRODUCTION}

An array of clinical symptoms, most of which are nonfatal, can be produced by lightning strike. Audiovestibular involvement is infrequently reported. Tympanic membrane rupture is most common otological injury (50-70\%) and transient vertigo is most common documented vestibular symptom caused by lightning strike..$^{[1,2]}$ Avulsion of the mastoid bone, burns to the external auditory canal, tinnitus, basilar skull fracture, ossicular disruption, perilymphatic fistula, cholesteatoma, and peripheral facial nerve palsy have also been reported following lightning strike. ${ }^{[2-4]}$ Presently described are 2 cases of hearing loss and I case of peripheral facial palsy with perilymphatic fistula after lightning strike. To our knowledge, the first patient is the first documented case of mid-frequency hearing loss after lightning strike and the third patient is the first documented case of facial palsy with perilymphatic fistula occurring at the same time.

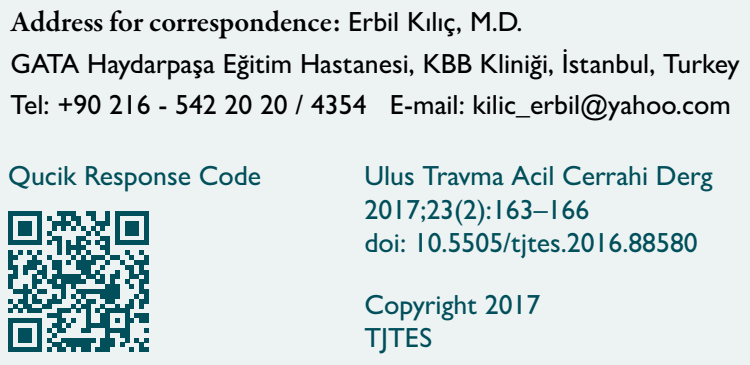

\section{CASE REPORT}

\section{Case 1}

A 31 -year-old male was referred to our hospital following witnessed lightning strike that occurred while patient was sitting on the ground in wooded area during thunderstorm. According to witness statement, victim was sitting under tree struck by lightning. The patient lost consciousness for almost $30 \mathrm{~min}-$ utes. When he regained consciousness in the ambulance, he was confused and had amnesia of event. On arrival at emergency department ( 2 hours after the incident), the patient was still confused. First- and second-degree burns were found covering his back, gluteal region, and neck. Second-degree burns were mostly located on gluteal region and back ( 13 bullous lesions). Linear skin lesions of first-degree burns were noted on back of neck and right side of occipital region. After confusion receded, patient began to suffer from dizziness, hearing loss in right ear, and tinnitus in left ear. Otological examination revealed mild hemotympanum of right ear with bilateral intact tympanic membranes. Although the patient experienced dizziness, vestibular examination was normal.

Pure tone audiometry test with audiometer (MA 53; Maico Diagnostic $\mathrm{GmbH}$, Berlin, Germany) of the right ear indicated mid-frequency hearing loss threshold of $60 \mathrm{~dB}$ at $1000 \mathrm{~Hz}$, $50 \mathrm{~dB}$ at $2000 \mathrm{~Hz}$, and $30 \mathrm{~dB}$ at $4000 \mathrm{~Hz}$. Bone conduction thresholds showed similar pattern. Pure tone audiometry 
test of the left ear revealed high frequency sensorineural hearing loss $(30 \mathrm{~dB}$ at $2000 \mathrm{~Hz}, 60 \mathrm{~dB}$ at $4000 \mathrm{~Hz}$, and 55 $\mathrm{dB}$ at $8000 \mathrm{~Hz}$ ) (Figure la). Soft tissue density/effusion in the right tympanic cavity was visible on temporal bone computed tomography (CT) (Brilliance CT 64-slice; Philips Healthcare N.V., Best, The Netherlands). Cranial magnetic resonance imaging (MRI) was normal.

The patient declined hyperbaric oxygen therapy and received intravenous (IV) methylprednisolone Img/kg (Prednol; Mustafa Nevzat llaç Sanayii A.S., Istanbul, Turkey), piracetam IV (Nootropil; UCB, S.A., Brussels, Belgium) and vitamin B complex IV (Bemiks 5; Zentiva, N.V., Prague, Czech Republic) for a week. Despite medication, however, audiometry testing revealed no change in right ear and only partial improvement $(20 \mathrm{~dB}$ at $2000 \mathrm{~Hz}, 40 \mathrm{~dB}$ at $4000 \mathrm{~Hz}$, and $50 \mathrm{~dB}$ at 8000 $\mathrm{Hz}$ ) in left ear (Figure lb). Conservative management was preferred for mild hemotympanum on right side, and I-week follow up resulted in complete resolution of hemotympanum. After cessation of I-week IV medication, intratympanic dexamethasone was administered to both ears once a day for 3 days. At conclusion of this treatment, high frequency hearing loss on the left side was recovered. Audiometry revealed threshold of $50 \mathrm{~dB}$ at $2000 \mathrm{~Hz}$ on the right; however, other frequencies were within normal limits (Figure Ic).

(a)

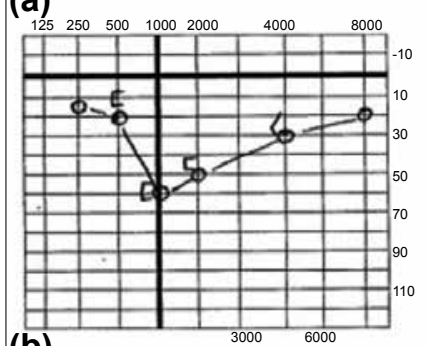

(b)
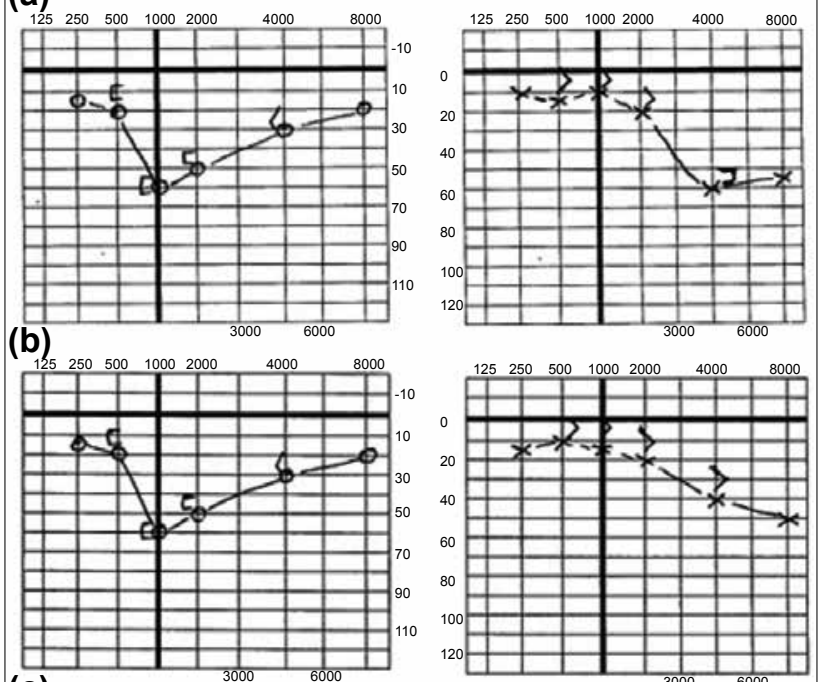

(c)
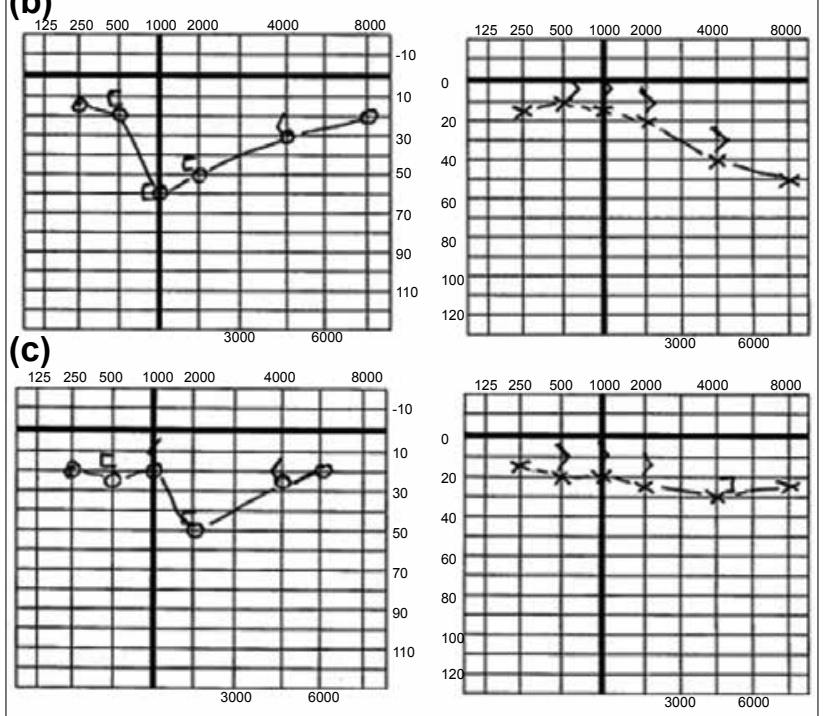

Figure 1. (Case 1) (a) Pure tone audiometry performed few hours after lightening strike. (b) Pure tone audiometry performed after initial medical treatment. (c) Pure tone audiometry performed after intratympanic dexamethasone treatment.

\section{Case 2}

A 21 -year-old male was referred to hospital following lightning strike. According to the patient, lightning struck tree that was 9 to 10 meters away from him. After loud noise, he noted tinnitus and left-side hearing loss a few seconds later and he was referred to local infirmary within an hour. He received single dose of methylprednisolone $1 \mathrm{mg} / \mathrm{kg}$ intravenously. Patient reported feeling some improvement in hearing loss following medication, but the patient presented to our department again the next day. Ear examination demonstrated bilateral intact and healthy tympanic membranes. Pure tone audiometry test performed I day after the incident revealed high frequency sensorineural hearing loss (40 dB at $4000 \mathrm{~Hz}$ and $50 \mathrm{~dB}$ at $8000 \mathrm{~Hz}$ ) in the left ear (Figure 2a). The patient received methylprednisolone $\mathrm{Img} / \mathrm{kg} \mathrm{IV}$, piracetam IV, and vitamin B complex IV for I day at hospital. Audiometry next day demonstrated normal hearing with resolution of all symptoms (Figure $2 b$ ).

\section{Case 3}

A 25-year-old male was admitted to the hospital I 5 days after lightning strike. According to referral letter from local otolaryngologist, who had seen the patient in first few hours after the incident, the patient lost consciousness for 5 hours. After regaining consciousness, the patient began to suffer from dizziness and hearing loss in his left ear. Spontaneous left-beating horizontal nystagmus, left-sided grade 4 peripheral facial palsy, mild hyperemia in left ear drum, and skin lesions of second-degree burns located on neck and gluteal region were observed on physical examination (Figure 3a).

On admission, physical examination demonstrated left-sided grade 3 peripheral facial palsy (Figures $3 b-d$ ), normal ear drums, and no spontaneous nystagmus; however, the patient still suffered from dizziness and left-sided hearing loss. Pure

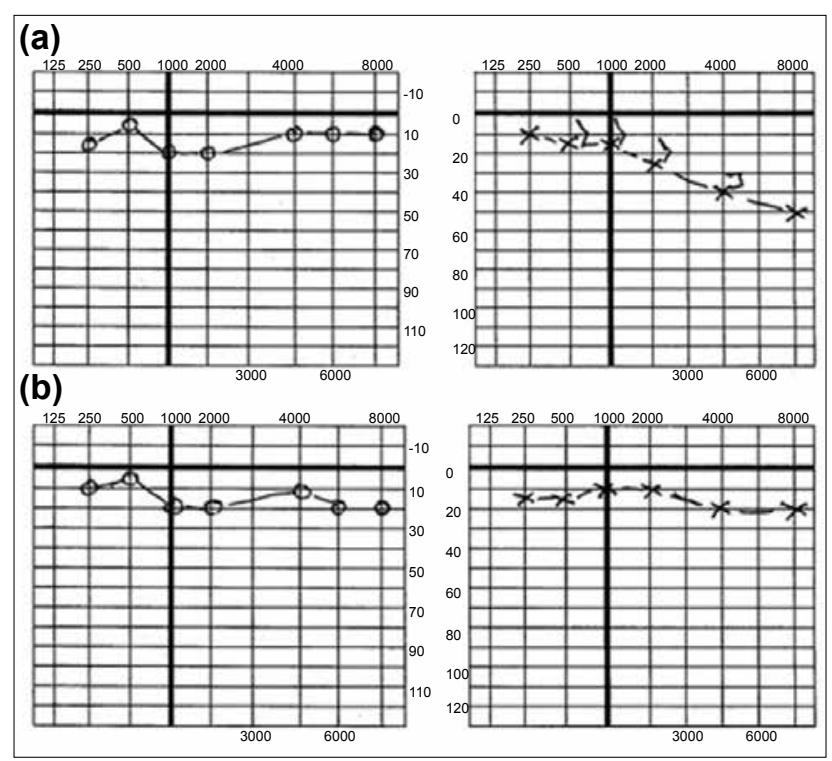

Figure 2. (Case 2) (a) Pure tone audiometry performed a day after the incident. (b) Pure tone audiometry performed after medical treatment. 

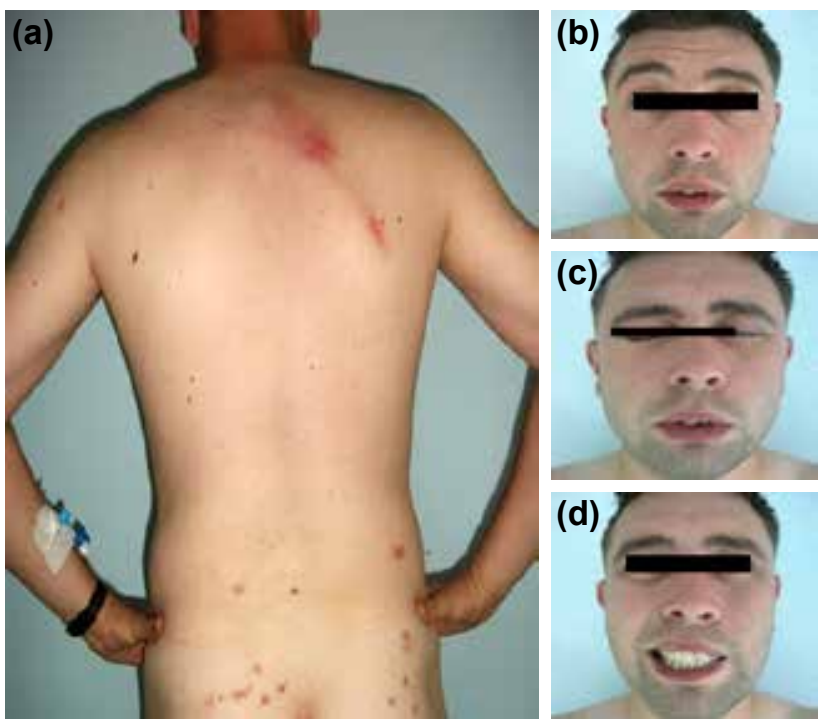

Figure 3. (Case 3) (a) Second-degree burns on the back and gluteal region. (b) Weak facial function on the left side of the forehead. (c) Slightly weak eyelid closure on the left. (d) Weak movement of the left corner of mouth.

tone audiogram revealed mixed hearing loss (with small gap) in the left ear (Figure 4a). Fistula test yielded positive response, especially with positive pressure. Temporal CT and $\mathrm{MRI}$ revealed no pathological finding.

Methylprednisolone I $\mathrm{mg} / \mathrm{kg}$ was administered for I week and exploratory tympanotomy was performed with tentative diagnosis of left-sided perilymphatic fistula. During exploration of the middle ear, perilymphatic leak from posterior leg of the stapes was observed and repaired with tragal cartilage perichondrium (Figure 5). One month later, low and high frequency hearing loss remained (Figure 4b). Facial function improved to normal level in 2 months.

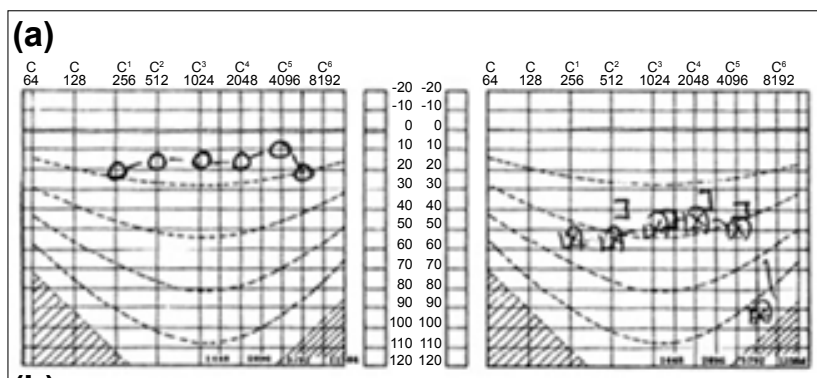

(b)

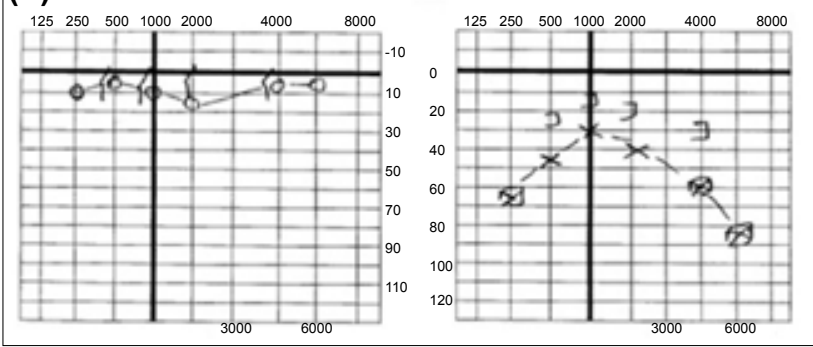

Figure 4. (Case 3) (a) Pure tone audiometry before surgery. (b) Pure tone audiometry after exploratory tympanotomy and repair of perilymphatic leak.

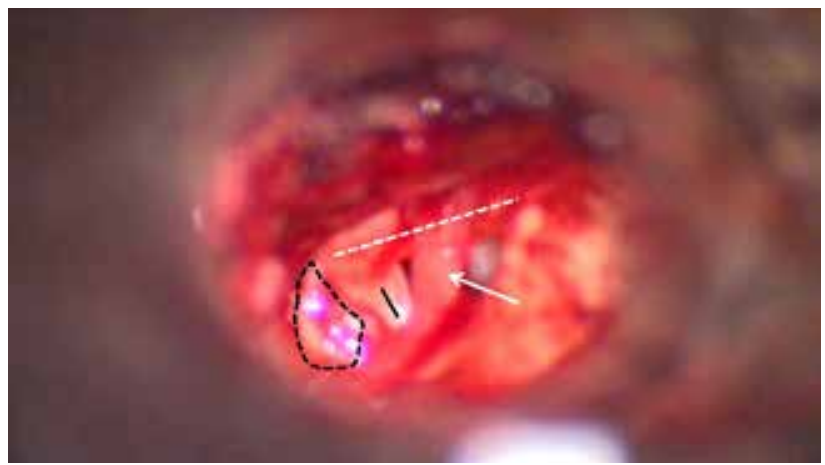

Figure 5. (Case 3) Repair of perilymphatic leak with perichondrium of tragal cartilage. Black dashed line: perichondrium of tragal cartilage, short black line: left stapedial tendon, white dashed line: the incus, white arrow: the chorda tympani.

\section{DISCUSSION}

Worldwide, it is estimated that there are some 8 million flashes of lightning per day. Electrical potential of lightning bolt is approximately 20 million volts with temperature exceeding $20000^{\circ} \mathrm{C}$. Current flow of lightning strike varies from 100 to 110.000 amperes. ${ }^{[1,5,6]}$

Since central audiovestibular system is extremely vulnerable to effects of lightning, all parts of hearing apparatus may be affected. ${ }^{[1,5,6]}$ Tympanic membrane rupture is most frequent otological damage caused by lightning strike. ${ }^{[1,2]}$ Dizziness, avulsion of the mastoid bone, burns to the external auditory canal, tinnitus, basilar skull fracture, ossicular disruption, peripheral facial nerve palsy, and deposit of squamous epithelium on the promontory are other reported clinical outcomes of lightning strike. ${ }^{[2,3,7]}$ Middle ear and mastoid effusion, degeneration of stria vascularis and organ of Corti, total rupture of Reissner's membrane, microfractures in otic capsule, and edema of facial nerve were also revealed in autopsy studies. ${ }^{[8]}$

Mechanisms of otological injuries caused by lightning strike remain controversial. Cylindrical shock wave transmission from external auditory canal to inner ear, which has enough force to rupture tympanic membrane and to cause ossicular disruption, is considered to be mechanism of otological injuries. High frequency hearing loss without middle ear or tympanic membrane lesions can be explained by acoustic effects of lightning. ${ }^{[3,9]}$ However, there are cases with intact middle and external ear developing sensorineural hearing loss, facial nerve palsy, ossicular disruption, and dizziness that cannot be explained by any of those mechanisms. ${ }^{[6,8,10]}$ Lightning bolt may directly damage inner ear, which has no bony structure in medial part, and may cause temporary occlusion of internal auditory artery. These are alternative theories to explain neural damage with intact middle and external ear. ${ }^{[1]}$ Use of earphones or telephone during thunderstorm has also been reported as possible risk factor for such ear injury. ${ }^{[3]}$

Sound of strike, which causes acute acoustic trauma, can be described as unexpected and of short duration but high inten- 
sity. A few cases of high frequency hearing loss after lightning strike have been reported. ${ }^{[2]}$ High frequency hearing loss in left ear of our patients was considered to be caused by acute acoustic trauma. High frequency hearing loss of third patient persisting after surgery can also be explained by acoustic effects of lightning.

Mid-frequency sensorineural hearing loss (cookie bite hearing loss or "U" shaped hearing loss) is uncommon. Most of these cases have hereditary or idiopathic etiology. A few cases of vestibular schwannoma have been reported as reason for mid-frequency hearing loss. To the best of our knowledge, the first patient described in this report is first documented case of mid-frequency hearing loss after lightning strike.

Low frequency hearing loss of third patient might be accounted for by slightly hindered motion of the stapes footplate due to sealing oval window with the perichondrium of tragal cartilage.

Little is known about mechanism of facial paralysis after lightning strike. Temporal bone fractures may cause facial paralysis. High temperature and electrical potential of lightning bolt can cause facial nerve edema. Finally, excessive stimulation may cause fatigue in facial nerve function. Relatively quick recovery of facial function in Case 3 would seem to support fatigue theory as result of excessive stimulation of lightning. Perilymphatic fistula likely resulted from exposure to excessive noise of lightning.

\section{Conclusion}

Severity of injury caused by lightning depends on amount of current carried and its derivative, charge transferred, and energy transferred. Distance between the victim and point of lightning strike is also important.

Lightning can cause different clinical symptoms and organ injuries, some of which can be fatal. During evaluation of victims of lightning strike in emergency department, comprehensive otological examination must be performed to avoid delay in detection of audiovestibular injuries.
Pathophysiology of audiovestibular damage following lightning strike is still unclear. Some theories and risk factors have been proposed as sources of otological injuries; however, none is yet sufficient to explain all clinical presentations.

Written, informed consent was obtained from the patients described in this report.

\section{Financial Disclosure}

The authors declare that this study received no financial support.

\section{Conflict of interest: None declared.}

\section{REFERENCES}

1. Browne BJ, Gaasch WR. Electrical injuries and lightning. Emerg Med Clin North Am 1992;10:211-29.

2. Ogren FP, Edmunds AL. Neuro-otologic findings in the lightning-injured patient. Semin Neurol 1995;15:256-62. Crossree

3. Offiah C, Heran M, Graeb D. Lightning strike: a rare cause of bilateral ossicular disruption. AJNR Am J Neuroradiol 2007;28:974-5.

4. Scalzitti NJ, Pfannenstiel TJ. A lightning strike causing a cholesteatoma: a unique form of otologic blast injury. Otol Neurotol 2014;35:298-300.

5. Cooper MA. Electrical and lightning injuries. J Emerg Med 1985;2:37988. Crossret

6. Wright JW Jr, Silk KL. Acoustic and vestibular defects in lightning survivors. Laryngoscope 1974;84:1378-87.

7. Seaman RW, Newell RC. Another etiology of middle ear cholesteatoma. Arch Otolaryngol 1971;94:440-2. Crossre]

8. Bergstrom L, Neblett LW, Sando I, Hemenway WG, Harrison GD. The lightning-damaged ear. Arch Otolaryngol 1974;100:117-21. Crossret

9. Mora-Magaña I, Collado-Corona MA, Toral-Martiñòn R, Cano A. Acoustic trauma caused by lightning. Int J Pediatr Otorhinolaryngol 1996;35:59-69. Crossret

10. Fidan V, Fidan T, Saracoglu KT. Lightning strike: a rare cause of incudostapedial disruption with intact membrane. Pediatr Emerg Care 2012;28:213-4.

11. Ilan O, Syed MI, Weinreb I, Rutka JA. Re: Inner ear damage following electric current and lightning injury: a literature review. Eur Arch Otorhinolaryngol 2015;272:3083-4. Crossre]

12. Angerer F, Hoppe U, Schick B. Lightning strike to a vehicle causing acute acoustic trauma. HNO 2009;57:1081-3. Crossret

\title{
OLGU SERISİ - ÖZET
}

\section{Yıldırım düşmesine bağlı oluşan farklı otolaringolojik tablolar: Üç hastaya ait klinik rapor}

\section{Dr. Erbil Kılıç, ${ }^{1}$ Dr. Hakan Genç, ${ }^{2}$ Dr. Ümit Aydın, ${ }^{3}$ Dr. Burak Aşık, ${ }^{4}$ Dr. Bülent Satar ${ }^{3}$}

\author{
${ }^{1}$ Gülhane Askeri Tıp Akademisi Haydarpaşa Eğitim Hastanesi, Kulak Burun Boğaz, Baş ve Boyun Cerrahisi Servisi, İstanbul \\ ${ }^{2}$ Isparta Asker Hastanesi, Kulak Burun Boğaz, Baş ve Boyun Cerrahisi Servisi, Isparta \\ ${ }^{3}$ Gülhane Askeri Tıp Akademisi, Kulak Burun Boğaz, Baş ve Boyun Cerrahisi Anabilim Dalı, Ankara \\ ${ }^{4}$ Şırnak Asker Hastanesi, Kulak Burun Boğaz, Baş ve Boyun Cerrahisi Servisi, Şırnak
}

Yıldırım düşmesi, ölümcül veya morbit yaralanmalara sebep olabilir. Bu morbit yaralanmaların bir kısmı otolaringolojik semptom ve bulgularla birliktedir. Yıldırım düşmesine bağlı yaralanmalarda en sık görülen odyovestibüler lezyon; timpanik membran rüptürüne bağlı iletim tipi işitme kaybıdır. Ayrıca çeşitli tiplerde sensörinöral işitme kaybı ve dizines da görülebilir. Bu yazıda, yıldııım düşmesine bağlı otolaringolojik lezyonu olan üç hastanın klinik tablosu sunuldu. İlk hastanın sağ kulağında orta-frekans işitme kaybı varken sol kulağında yüksek frekans sensörinöral işitme kaybı vardı. İkinci hastanın sağ kulağında sadece yüksek frekans sensörinöral işitme kaybı vardı. Üçüncü hastada ise, yıldırım çarpması sonrası, periferik fasiyal paralizi ve aynı tarafta perilenf fistülü tespit edildi. Yıldıım çarpması sonrasında bir kulağında orta-frekans işitme kaybı oluşan hastamız, yıldıım çarpması sonrası orta-frekans sensörinöral işitme kaybı meydana gelen literatürde bildirilmiş ilk hastadır.

Anahtar sözcükler: Orta-frekans işitme kaybı, periferik fasiyal paralizi; perilenf fistülü; yıldırım çarpması; yüksek frekans işitme kaybı. 